\title{
KAJIAN YURIDIS TERHADAP PERKAWINAN POLIGAMI YANG TIDAK TERCATAT (Studi Penelitian di Desa Kota Panton Labu Kecamatan Tanah Jambo Aye Kabupaten Aceh Utara)

\author{
${ }^{1}$ Annisa, ${ }^{2}$ Teuku Yudi Afrizal, ${ }^{2}$ T. Saifullah \\ Email :teukuyudiafrizal@unimal.ac.id
} \\ ${ }^{1}$ Mahasiswa Fakultas Hukum Universitas Malikussaleh \\ ${ }^{2}$ Dosen Fakultas Hukum Universitas Malikussaleh
}

\begin{abstract}
Abstrak
Poligami adalah suatu perkawinan yang dilakukan oleh seorang laki-laki dengan lebih dari satu orang isteri tanpa menceraikan isteri-isteri yang lain. Poligami merupakan sesuatu yang terjadi dalam suatu kehidupan bermasyarakat ketika seorang suami merasa mampu dan dapat berlaku adil terhadap isteri-isteri dan anak-anaknya sehingga dapat tercapai keharmonisan dalam keluarga. Dalam hukum Islam maupun Hukum positif tidak ada larangan untuk melakukan poligami tersebut. Akan tetapi harus melalui aturan dan prosedur dan aturan hukum yang berlaku serta dengan alasan-alasan yang dapat dijadikan dalil untuk melakukan poligami. Penelitian ini bertujuan untuk mengetahui faktor yang menyebabkan terjadinya perkawinan poligami yang tidak tercatat, akibat hukum dari perkawinan poligami terhadap isteri dan anak-anak yang tidak dicatat, dan penyelesaian hukum terhadap perkawinan poligami yang tidak dicatat. Penelitian ini digunakan metode pendekatan yuridis empiris bersifat deskriptif. Jenis data meliputi data primer dan data sekunder yang dikumpulkan melalui penelitian kepustakaan dan serta penelitian lapangan (field research). Berdasarkan dari hasil penelitian masih terdapat suami yang melakukan perkawinan poligami yang tidak tercatat, hal itu menyebabkan permasalahan bagi isteri dan anak-anak yang terlahir dari perkawinan tersebut khususnya hak anak dalam perlindungan tertentu bagi mereka baik status, harta dan juga kasih sayang. Perkawinan poligami yang tidak dicatat menyebabkan sebagian anak yang menjadi korban karena tidak mempunyai identitias resmi di hadapan hukum dan dampak terhadap isteri mengabaikan hak-hak isteri dan status perkawinan dengan isteri kedua tidak mempunyai kekuatan hukum. Disarankan kepada masyarakat khususnya yang melakukan perkawinan poligami yang menjadi faktor penyebab terjadinya poligami karena kurang memahami hal yang mebolehkan berpoligami serta berdasarkan atas dorongan nafsu syahwatnya saja dan tidak adanya rasa tanggung jawab suami terhadap isteri dan anak-anaknya.
\end{abstract}

Kata Kunci: Perkawinan, Poligami, Akibat Hukum. 


\section{PENDAHULUAN}

Perkawinan merupakan salah satu peristiwa penting dalam kehidupan manusia. Perkawinan yang terjadi antara seorang pria dengan seorang wanita menimbulkan akibat lahir batin baik terhadap keluarga masing-masing masyarakat dan juga dengan harta kekayaan yang diperoleh diantara mereka baik sebelum maupun selama perkawinan berlangsung. Perkawinan juga merupakan Sunatullah bagi umat manusia. Hal ini ditetapkan Allah untuk menjaga kehormatan umat manusia dan juga untuk membedakan umat manusia dengan makhluk lainnya. Sudah menjadi kodrat segala sesuatu yang ada di dunia ini mempunyai pasangan masing-masing. Perkawinan merupakan salah satu perintah Agama kepada yang mampu untuk segera melaksanakannya, karena perkawinan dapat mengurangi kemaksiatan, baik dalam bentuk penglihatan maupun dalam bentuk perzinaan. Akad perkawinan dalam Hukum Islam bukanlah perkara perdata semata, melainkan ikatan suci (mitsaqan gholidzan) yang terkait dengan keyakinan dan keimanan kepada Allah. ${ }^{1}$

Pada Pasal 1 Undang-Undang Perkawinan (selanjutnya disebut Undang-Undang Perkawinan) bahwa, pengertian perkawinan adalah" Sebagai ikatan lahir bathin antara seorang pria dengan seorang wanita sebagai suami isteri yang bertujuan untuk membentuk keluarga (rumah tangga) yang bahagia dan kekal berdasarkan Ketuhanan Yang Maha Esa." 2

Perkawinan dalam Islam pada dasarnya menganut asas monogami, karena asas tersebut yang lebih dapat menjamin terpenuhinya hak-hak isteri. Namun demikian, Islam membolehkan suami melakukan poligami disertai dengan syarat-syarat yang ketat. Poligami bukanlah suatu hal yang dianjurkan dalam Agama Islam, sebaliknya juga bukan merupakan suatu larangan. Tetapi Islam memberikan peluang untuk poligami sebagai upaya untuk mengatasi kepentingan yang berkaitan dengan kemaslahatan masyarakat dan para pelakunya dan bukan sebagai praktik coba-coba atau sekedar untuk menyalurkan seks semata. Poligami adalah jalan keluar kepada manusia yang telah disediakan untuk mengatasi kesulitan dan merupakan jalan keluar bagi mereka yang belum atau tidak menemukan tujuan yang didambakan dalam perkawinan baik yang pertama maupun yang selanjutnya. Islam membatasi poligami walaupun Islam menghapus poliandri. Islam hanya membatasinya sampai empat orang isteri saja, lagi pula Islam menetapkan syarat dan batasnya, dan tidak mengizinkan setiap orang mempunyai beberapa isteri. ${ }^{3}$

Poligami merupakan satu persoalan klasik tetapi selalu aktual dalam kehidupan bermasyarakat. Poligami merupakan persoalan sulit yang dihadapi oleh kaum wanita. Poligami bisa menimpa siapa saja, guru, ibu rumah tangga, pejabat, dai, kiai, bahkan artis pun tidak jarang yang tersangkut dalam permasalahan tentang poligami. Poligami

\footnotetext{
1 Zainuddin Ali, Hukum Perdata Islam di Indonesia, Sinar Grafika, Jakarta, 2006, hlm. 7

${ }^{2}$ Undang-Undang Nomor 1 Tahun 1974 tentang Perkawinan, Pasal 1.

${ }^{3}$ Murtadha Muthahari, Citra Wanita Terhormat, Pustaka Zahra, Jakarta, 2003, hlm. 217
} 
merupakan salah satu tema penting yang mendapat perhatian khusus dari Allah SWT. Sebagaimana yang terdapat dalam Al-qur'an surat An-Nisa' ayat 3 yang artinya: ${ }^{4}$

"Dan jika kamu khawatir tidak akan mampu berlaku adil terhadap (hak-hak) perempuan yatim (bilamana kamu menikahinya), maka nikahilah perempuan (lain) yang kamu senangi: dua, tiga atau empat. Tetapi jika kamu khawatir tidak akan mampu berlaku adil, maka (nikahilah) seorang saja, atau hamba sahaya perempuan yang kamu miliki. Yang demikian itu lebih dekat agar kamu tidak berbuat zalim.

Dari ayat diatas dapat dipahami bahwa seorang laki-laki boleh memiliki satu, dua, tiga atau bahkan empat isteri, dengan syarat mampu berlaku adil jika tidak mampu maka cukup satu orang isteri saja. Berlaku adil yang dimaksud adalah dapat memenuhi kebutuhan-kebutuhan isteri dan anak-anak.

Islam sudah mengatur masalah poligami, namun masih banyak kalangan menolak kebolehan hukum poligami karena dianggap tidak adil dan mendiskriminasikan salah satu pihak terutama perempuan. Dalam tata hukum Indonesia, persoalan poligami diatur dalam Undang-Undang Perkawinan dan Kompilasi Hukum Islam. Di dalamnya memuat berbagai macam syarat yang harus dipenuhi seorang suami ketika hendak melakukan poligami. Dari syarat-syarat yang ditetapkan dapat dilihat bahwa melakukan poligami bukanlah hal yang mudah, karena syaratnya yang sangat ketat. Praktik poligami di Indonesia tetap marak terjadi, dalam masyarakat begitu banyak alasan yang menyebabkan seseorang melakukan poligami. Dari hal-hal yang sepele yang terkadang tidak dapat diterima dengan akal pikiran dan bertentangan dengan nilai keadilan dan persamaan hak antara laki-laki dan perempuan sampai kepada hal-hal yang memang diperbolehkan oleh syariat serta tidak menodai rasa keadilan dan hati nurani. Salah satunya adalah karena alasan seorang isteri tidak mampu memenuhi kewajiban sebagai seorang isteri terhadap suami. ${ }^{5}$

Berdasarkan Undang-Undang Perkawinan Pasal 3 ayat (1) menentukan "Pada asasnya dalam suatu perkawinan seorang pria hanya boleh mempunyai seorang isteri, seorang isteri hanya boleh mempunyai seorang suami”. Pasal 3 ayat (2) yang berbunyi: "Pengadilan dapat memberi izin kepada seorang suami untuk beristri lebih dari seorang apabila dikehendaki oleh pihak-pihak yang bersangkutan". 6

Pengadilan hanya akan memberi izin kepada suami untuk beristeri lebih dari satu apabila (Pasal 4 UU Nomor 1 Tahun 1974) yaitu Isteri tidak dapat menjalankan kewajiban sebagai isteri, Isteri mendapat cacat badan atau penyakit yang tidak dapat disembuhkan, dan isteri tidak dapat melahirkan keturunan. ${ }^{7}$

Kenyataan dalam masyarakat Desa Kota Panton Labu Kecamatan Tanah Jambo Aye, perkawinan poligami itu dilakukan diluar izin dari isteri-isteri mereka. Sehingga hlm. 425

${ }^{4}$ Muhammad Shahrur, Metodologi Fiqih Islam Kontemporer, Elsaq Press, Yogyakarta, 2006,

${ }^{5}$ Labib MZ, Pembelaan Ummat Manusia, Bintang Pelajar, Surabaya, 2006, hlm. 17

${ }^{6}$ Undang-Undang Nomor 1 Tahun 1974 tentang Perkawinan, Pasal 3 ayat (1-2)

7 Undang-Undang Nomor 1 Tahun 1974 tentang Perkawinan, Pasal 4 
perkawinan tersebut tidaklah mempunyai kekuatan hukum. Praktek poligami yang terjadi di Desa Kota Panton Labu sama dengan praktek nikah sirri. Padahal dalam Undang-Undang Perkawinan Pasal 2 ayat (2) menyebutkan bahwa " Tiap-tiap perkawinan dicatatkan menurut peraturan perundang-undangan yang berlaku". ${ }^{8}$ Namun realita yang terjadi di Desa Kota Panton Labu ada beberapa orang yang melakukan poligami diluar izin isteri-isteri mereka yang mengakibatkan percekcokan, pertengkaran dan juga hilangnya keharmonisan dalam rumah tangga. Dengan kata lain poligami dilaksanakan tanpa peduli dengan syariat yang telah mengaturnya, seakan mereka lupa bahwa poligami pada saatnya juga akan dipertanggung jawabkan dihadapan Allah SWT. Karena itu kesan yang melekat pada kebanyakan manusia, poligami adalah pengaruh syahwat, realitas juga menunjukkan betapa banyak kemelaratan, kesengsaraan, dan penghancuran keluarga hanya karena poligami. ${ }^{9}$

Berdasarkan penelitian awal yang dilakukan Desa Kota Panton Labu masih terdapat sebagian suami yang melakukan poligami yang tidak dicatat. Hal itu menyebabkan permasalahan bagi isteri dan anak-anak yang terlahir dari perkawinan tersebut khususnya hak anak untuk perlindungan tertentu bagi mereka baik status, harta dan juga kasih sayang. ${ }^{10}$ Tetapi dalam kondisi perkawinan poligami yang tidak dicatat justru menimbulkan banyak permasalahan yang terjadi yang mengancam keutuhan dan keharmonisan rumah tangga terutama mengenai hak-hak terhadap isteri dan juga dampaknya terhadap anak dari hasil perkawinan poligami yang tidak tercatat. Adapun dimaksud mengenai hak perempuan atau hak isteri dalam perkawinan poligami yang tidak tercatat adalah hak untuk berumah tangga atau keadilan suami terhadap isteri. Berbeda sekali dengan hak atas perkawinan bagi seorang laki-laki atau suami ialah hak memuaskan naluri, memperoleh isteri, jodoh, teman setia dan memperoleh anak yang sah.

Berdasarkan hasil penelitian perkawinan poligami yang tidak tercatat menyebabkan sebagian anak yang menjadi korban karena tidak tercatat di catatan sipil tidak mempunyai identitas resmi di hadapan hukum. Pelaksanaan perkawinan poligami yang tidak tercatat juga memberikan dampak negatif, dampak negatif itu terlihat pada anak, isteri dan pelaku poligami itu sendiri. Hal ini diperlukan dengan pertimbangan bahwa efektif tidaknya berlaku suatu aturan hukum sangat dipengaruhi oleh berbagai faktor seperti perubahan pola berpikir masyarakat

Berdasarkan uraian diatas, maka penulis tertarik mengkaji lebih dalam tentang "Kajian Yuridis Terhadap Perkawinan Poligami Yang Tidak Tercatat (Studi Penelitian di Desa Kota Panton Labu, Kecamatan Tanah Jambo Aye, Kabupaten Aceh Utara)".

\footnotetext{
8 Undang-Undang Nomor 1 Tahun 1974 tentang Perkawinan, Pasal 2 ayat (2)

${ }^{9}$ Hasan Edy, Poligami Syariah dan Perjuangan Kaum Perempuan, Alfabeta, Bandung, 2007, hlm. 61

${ }^{10}$ Asrorum Ni'am Sholeh, Fatwa-Fatwa Masalah Pernikahan dan Keluarga, Elsas, Jakarta, 2008, hlm. 191-192
} 


\section{METODE PENELITIAN}

Studi penelitian ini menggunakan jenis penelitian kualitatif, yaitu dengan cara peneliti terjun langsung kelapangan guna menghasilkan data deskriptif, yaitu data yang dinyatakan oleh responden secara tertulis atau lisan serta tingkah laku yang nyata, yang diteliti dan dipelajari sebagai sesuatu yang utuh. ${ }^{11}$ Dan pendekatan kualitatif yang menghasilkan data deskriptif ini bersifat menggambarkan/menguraikan sesuatu hal apa adanya dari tulisan/ungkapan dan tingkah laku yang dapat diobservasi sehingga nantinya penulis dapat mendeskripsikan tentang Kajian Yuridis Terhadap Perkawinan Poligami yang tidak tercatat di Kota Panton Labu Kecamatan Tanah Jambo Aye Kabupaten Aceh Utara.

Adapun pendekatan penelitian yang digunakan adalah yuridis empiris, yaitu prosedur penelitian yang dilakukan dengan menemukan teori-teori mengenai proses sebenarnya bekerjanya hukum dalam lingkungan hidup bermasyarakat. ${ }^{12}$

Analisis data yang digunakan dalam penelitian ini adalah analisis kualitatif yaitu tehnik analisis data yang menjelaskan data yang diperoleh dari penelitian lapangan (hasil wawancara) maupun keperpustakaan yang dianalisis kedalam bentuk uraianuraian sehingga pada akhirmya dapat menjawab permasalahan yang ada. Analisis bahan hukum adalah proses menyusun data agar dapat ditafsirkan. Dalam penelitian kualitatif, analisis data dilakukan sejak awal dan terus berjalan sepanjang proses penelitian berlangsung.

\section{PEMBAHASAN}

\section{Penyebab Terjadinya Perkawinan Poligami yang Dilakukan Masyarakat Kota Panton Labu yang Tidak Tercatat}

Menurut Undang-Undang Perkawinan dan Peraturan Pemerintah Nomor 9 Tahun 1975 menggunakan istilah "Poligami" yang sudah populer dalam masyarakat. Beristeri lebih dari satu orang dapat dibenarkan bila dapat memenuhi beberapa alasan dan syara-syarat tertentu yang ditetapkan dalam Undang-Undang Perkawinan dan perkawinan dapat dilaksanakan apabila mendapatkan izin dari isteri pertamanya dan ada izin dari Pengadilan Agama terlebih dahulu. ${ }^{13}$

Poligami atau perkawinan lebih dari satu orang merupakan suatu persoalan yang sangat sulit bagi kaum wanita. Pelaksanaan poligami atau kawin lebih dari satu orang isteri, maka akan menimbulkan hal-hal yang bersifat negatif dalam menegakkan rumah tangganya. Biasanya hubungan dengan isteri kedua dan isteri pertama tidak pernah akur, sementara anak-anak yang berlainan ibu juga tidak harmonis yang dapat membahayakan

${ }^{11}$ Mukti Fajar ND dan Yulianto Achmad, Dualisme penelitian Hukum, Normatif dan Empiris, Yogyakarta, Pustaka Pelajar, 2010, hlm. 192

12 Bambang Sunggono, Metode Penelitian Hukum, Cetakan Ketiga, UI Press, Jakarta 1986, $\operatorname{hlm} .5$

${ }^{13}$ Abdul Manan, Op. Cit., hlm. 9. 
kelangsungan hidupnya, hal ini biasanya terjadi jika ayah telah meninggal dunia. Agar hal-hal yang bersifat negatif itu tidak terjadi dalam rumah tangga, orang-orang yang ingin menikah lebih dari satu orang isteri, maka undang-undang perkawinan ini membatasi secara ketat pelaksanaan perkawinan yang demikian itu, dengan mengatisipasi lebih awal dalam membatasi menikah lebih dari satu orang itu dengan alasan-alasan dan syarat-syarat tertentu. ${ }^{14}$ Dalam Pasal 4 Undang-Undang Perkawinan ada 3 (tiga) alasan yang dapat dijadikan sebagai alasan untuk berpoligami, Pengadilan hanya memberikan izin kepada seorang suami yang akan beristeri dari seorang apabila isteri tidak bisa menjalankan kewajibannya sebagai isteri, isteri mendapatkan cacat atau penyakit yang tidak dapat disembuhkan, dan isteri tidak dapat melahirkan keturunan. ${ }^{15}$

Perkawinan poligami dalam Islam memang tidak dilarang dan tidak pula diperintahkan, akan tetapi diperbolehkan bagi orang-orang tertentu saja yang bisa memenuhi persyaratan yang telah diatur secara ketat dalam Undang-undang Perkawinan dan Kompilasi Hukum Islam. Ada beberapa syarat yang diperbolehkan melakukan poligami terutama yaitu alasan suami berpoligami, adanya persetujuan isteri, adanya kemampuan suami menafkahi isteri dan anak-anaknya, dan adanya jaminan suami mampu berlaku adil terhadap isteri-isterinya.

Praktek poligami yang terjadi di Kota Panton Labu Kecamatan Tanah Jambo Aye dilakukan secara diam-diam dalam melakukan perkawinan poligami yang tidak tercatat. Dan tanpa izin dari isteri pertamanya terlebih dahulu juga dilakukan dengan berbagai alasan diluar ketentuan yang berlaku.

Berdasarkan informasi yang diperoleh dari pelaku poligami yaitu Bapak Amir yang bekerja sebagai penampung buah kepala bahwa faktor yang menyebabkan kan Bapak Amir melakukan poligami yaitu dikarenanakan isteri pertamanya yang tidak bisa memberikan keturunan, Justru dalam Undang-Undang Perkawinan pada Pasal 4 ayat (2) pengadilan hanya memberikan izin kepada seorang suami yang akan beristeri lebih dari seorang apabila; Isteri tidak dapat menjalankan kewajibannya sebagai isteri, Isteri mendapatkan cacat badan atau penyakit yang tidak dapat disembuhkan dan Isteri tidak dapat melahirkan keturunan. Tetapi Bapak Amir melakukan perkawinan poligami secara tidak sah yaitu dengan cara nikah sirri dikarenakan dia tidak berani untuk meminta izin kepada isteri pertamanya dan beliau melakukan perkawinan poligaminya tersebut secara diam-diam tanpa sepengetahuan isteri pertama dan juga keluarga isteri pertamanya.

Dan menurut informasi yang diperoleh dari Bapak Mustafa, beliau melakukan perkawinan poligami yang tidak tercatat dikarenakan proses dalam memenuhi persyaratan poligami di pengadilan yang sangat sulit dikarenakan faktor tempat tinggal dengan siteri pertamanya dan juga ada kendala perdebatan antara Bapak Mustafa dengan Ibu mertuanya, dan akhirnya Bapak Mustafa memutuskan untuk melakukan perkawinan poligami dengan secara nikah sirri di kampung halamanya sendiri. Dalam Undang-Undang Perkawinan dan Kompilasi Hukum Islam cukup jelas dengan syarat-

${ }^{14}$ Ibid., hlm. 10.

15 Undang-Undang Perkawinan, Pasal 4. 
syarat yang membolehkan untuk melakukan poligami dan bahkan Bapak Mustafa tersebut sudah diberikan izin oleh isteri pertamanya tetapi beliau tetap melakukan perkawinan dengan isteri kedua secara tidak sah.

Berdasarkan hasil temuan dilapangan, Faktor yang menyebabkan perkawinan poligami yang tidak tercatat yang terjadi di masyarakat Kota Panton Labu adalah dilakukan berdasarkan kurangnya pemahaman tentang syarat-syarat dan alasan dalam melakukan poligami dan pencatatan perkawinan. Di dalam hukum Islam poligami dibolehkan, tetapi bukan berarti dapat melakukan perkawinan poligami tanpa memenuhi syarat-syarat tertentu yang sudah ditetapkan dalam Kompilasi Hukum Islam. Dan begitu juga menurut ketentuan-ketentuan yang terdapat dalam Undang-Undang Perkawinan pada prinsipnya asas yang dianut oleh hukum perkawinan di Indonesia adalah asas monogami, satu suami untuk satu isteri. Namun dalam hal atau alasan tertentu seorang suami dapat diizinkan untuk beristeri lebih dari seorang dapat dibenarkan asal dapat terpenuhi beberapa alasan dan syarat tertentu yang telah ditetapkan oleh UndangUndang Perkawinan yang dapat dilaksanakan apabila ada izin isteri dan izin dari pengadilan Agama terlebih dahulu.

\section{Akibat Hukum Dari Perkawinan Poligami Yang Tidak Tercatat Terhadap Isteri dan Anak yang Dilahirkan.}

Pencatatan nikah dalam perspektif Undang-Undang Perkawinan diatur dalam pasal 2 ayat (2) Tiap-tiap perkawinan dicatat menurut peraturan perundang-undangan. Dalam Undang-Undang ini mengharuskan adanya pencatatan nikah menurut peraturan perundang-undangan yang berlaku. Pencatatan setiap perkawinan sama halnya dengan pencatatan suatu peristiwa hukum dalam kehidupan seseorang misalnya kelahiran, kematian yang dinyatakan dalam suatu akta resmi (surat keterangan) yang dimuat dalam daftar pencatatan yang disediakan khusus untuk itu. ${ }^{16}$

Perkawinan yang tidak dicatat bertentangan dengan Undang-Undang Perkawinan yaitu pada Pasal 2 ayat (2) bahwa setiap perkawinan harus dicatat. Oleh karena itu, perkawinan yang tidak tercatat memiliki konsekuensi hukum diantaranya yaitu meski perkawinan dilakukan menurut agama dan kepercayaan namun dimata negara perkawinan tersebut tidak diakui oleh negara jika belum dicatat di Kantor Urusan Agama atau Kantor Catatan Sipil, Perkawinan yang tidak dicatat kesulitan dalam hal administratif, tidak memiliki sebuah dokumen resmi (akte nikah) yang bisa dijadikan sebagai alat bukti di hadapan pengadilan ketika ada sengketa yang berkaitan dengan perkawinan maupun sengketa yang lahir akibat perkawinan seperti harta warisan, perceraian,nafkah isteri, dan hak asuh anak yang dilahirkan dari perkawinan yang tidak dicatatkan maka hak asuhnya jatuh kepada isteri jika terjadi perceraian. Nafkah dan warisan terhadap perkawinan yang tidak dicatatkan diselesaikan secara kekeluargaan, akan tetapi biasanya ketika terjadi perceraian suami tidak memberikan nafkah kepada isteri.

${ }^{16}$ Subekti \& Tjitrosudibio, Kitab Undang-Undang Hukum Perdata, Jakart, 2002, hlm. 560. 
Anak sebagai hasil dari suatu perkawinan merupakan bagian yang sangat penting kedudukannya dalam suatu keluarga, Seorang anak yang sah ialah anak yang lahir dari perkawinan yang sah antara ayah dan ibunya dan dari perkawinan yang tercatat. Anak-anak yang terlahir dalam perkawinan yang tidak tercatat dianggap sebagai anak tidak sah atau anak luar nikah.

Dan dampak akibat terhadap isteri dari perkawinan poligami yang tidak tercatat sangat berdampak merugikan bagi isteri dan perempuan umumnya, baik secara hukum maupun sosial yaitu tidak dianggap isteri sah, tidak berhak atas nafkah dan warisan dari suami jika suaminya meninggal dunia, tidak berhak atas harta gono-gini jika terjadi perpisahan karena secara hukum perkawinan poligami yang tidak tercatat dianggap tidak pernah terjadi, perempuan dari hasil poligami tidak tercatat akan sulit bersosialisasi karena perempuan tersebut sering dianggap telah tinggal serumah dengan laki-laki tanpa ikatan perkawinan tidak sah atau dianggap menjadi isteri simpanan. ${ }^{17}$

Akibat hukum dari perkawinan poligami yang tidak tercatat terhadap anak adalah anak tidak dapat mengurus akta kelahiran, Ketidak jelasan status hukum anak hasil dari perkawinan tersebut mengakibatkan hubungan antara ayah dan anak menjadi tidak kuat, sehingga ayahnya dapat menyangkal bahwa anak tersebut bukan anak kandungnya. Permohonan Akta Kelahiran yang diajukan kepada Kantor Catatan Sipil bila tidak dapat menunjukkan akta nikah anak tersebut maka dalam akta kelahiran anak tersebut diatas statusnya dianggap sebagai anak luar nikah, tidak tertulis nama ayah kandungnya dan hanya tertulis ibu kandungnya saja. Akibat lebih jauh dari perkawinan yang tidak tercatat adalah anak-anak yang dilahirkan dari perkawinan tersebut tidak berhak menuntut nafkah, biaya pendidikan, ataupun warisan dari ayahnya.

Dampak dari perkawinan poligami yang tidak tercatat anak-anak tidak dapat mewarisi harta orang tuanya karena tidak ada bukti autentik yang menyatakan mereka sebagai ahli waris orang tuanya. Akibat lebih jauh dari perkawinan poligami yang tidak tercatat adalah baik isteri maupun anak-anak yang dilahirkan dari perkawinan poligami yang tidak tercatat tidak berhak menuntut nafkah maupun warisan dari ayahnya.

Berdasarkan hasil penelitian dengan responden di Kota Panton Labu yang diteliti, bahwa penulis telah menemukan adanya dampak akibat hukum terhadap anak yang dilahirkan dari perkawinan poligami yang tidak tercatat dan juga dampak terhadap isteri. Yang pertama, anak tidak dapat mengurus akta kelahiran sebab orang tua nya tidak memiliki akta nikah, yang kedua kelahiran si anak tersebut tidak di akui oleh Negara dari perkawinan ayah dan ibu nya yang tidak dicatatkan ke Kantor Urusan Agama atau Kantor Catatan Sipil dan akibat Terhadap isteri, perkawinan poligami yang tidak tercatat yaitu tidak dianggap isteri sah, tidak berhak atas nafkah dan warisan dari suami jika suaminya meninggal dunia, tidak berhak atas harta gono-gini jika terjadi perpisahan karena secara hukum perkawinan poligami yang tidak tercatat dianggap tidak pernah terjadi,perempuan yang melakukan poligami tidak tercatat akan sulit

17Masykurotus Syarifah, Implikasi Yuridis Poligami Bawah Tangan Perspektif UU No. 1 Tahun 1974 Tentang Perkawinan, Jurnal Yustitia, Vol.19 N0.1, Sekolah Tinggi Agama Islam (STAI), 2018, hlm. 32 
bersosialisasi karena perempuan yang melakukan poligami tidak tercatat sering dianggap telah tinggal serumah dengan laki-laki tanpa ikatan perkawinan tidak sah atau dianggap menjadi isteri simpanan.

\section{Penyelesaian Hukum Terhadap Perkawinan Poligami Yang Tidak Tercatat}

Perkawinan yang sah adalah sah menurut hukum Agama dan hukum Negara (Perkawinan yang dicatatkan), begitu pula sebaliknya perkawinan yang hanya dilakukan menurut rukun dan syarat sahnya nikah secara hukum Islam tetapi tidak dicatatkan, menjadi tidak sah secara hukum Negara dan mirisnya lagi perkawinan tersebut dianggap tidak pernah ada. Dan ketika dari perkawinan yang tidak dicatatkan tersebut menghasilkan keturunan maka status anak tersebut menjadi anak tidak sah atau anak diluar nikah. Dalam Undang-Undang Perkawinan Pasal 24, menyatakan bahwa"Anak sah adalah anak yang dilahirkan dalam atau sebagai akibat perkawinan yang sah pula." Sedangkan pada Pasal 43 Undang-Undang Perkawinan menyatakan bahwa"Anak yang dilahirkan diluar perkawinan hanya mempunyai hubungan perdata dengan ibunya dan keluarga ibunya saja."18

Untuk mengesahkan suatu pernikahan sirri sebenarnya dapat dilakukan secara Isbat Nikah dengan mengajukan permohonan pengesahan pernikahan sirri ataupun pengajuan gugatan pernikahan sirri. Namun sejak disahkannya Undang-Undang Perkawinan pengajuan Isbat Nikah sulit dikabulkan kecuali pengajuan Isbat Nikah dalam rangka perceraian. Pengajuan pengesahan pernikahan sirri diajukan ke Pengadilan Agama melalui Isbat Nikah terbatas pada hal-hal yang dalam Pasal 7 ayat (3) KHI sebagaimana telah disinggung diatas. ${ }^{19}$

Terhadap permohonan atau gugatan pengesahan nikah sirri poligami tersebut akan menjadi bahan pertimbangan hakim apakah poligami sirri tersebut dilakukan suami hanya untuk memperturutkan hawa nafsu atau sebagai pintu darurat dimana si isteri sah tidak memberikan izin, padahal kondisi isteri termasuk dalam suatu kondisi yang menjadi salah satu alasan bagi suami melakukan poligami dan apabila permohonan Isbat Nikah poligami sirri yang diajukan untuk rekreasi seksual, bukan sebagai pintu darurat maka, keputusan tersebut dinyatakan tidak dapat diterima. Apabila putusan hakim mengabulkan gugatan pengesahan nikah sirri poligami yang diajukan tersebut, maka dapat dijadikan dasar pencatatan pernikahan sirri, selanjutnya pemohon dapat mengurus pencatatannya di Kantor Urusan Agama setempat dan untuk administrasi kependudukan lainnya dapat dilakukan di Kantor Administrasi kependudukan dan Catatan Sipil setempat termasuk untuk pengurusan akta kelahiran anak.

Penyelesaian terhadap anak-anak yang dilahirkan dari perkawinan poligami yang tidak tercatat, maka perlindungan hukum terhadap anak tersebut dengan dikabulkan permohonan orang tua perihal Isbat Nikah Poligami maka status perkawinannya menjadi sah begitu pula anak yang terlahir dari perkawinan yang tidak

18 Undang-Undang Nomor 1 Tahun 1974 Tentang Perkawinan, Pasal 42,43

${ }^{19}$ Kompilasi Hukum Islam, Pasal 7 ayat (3) 
dicatatkan tersebut berubah status menjadi anak sah bukan lagi anak diluar nikah. Yang pada akhirnya berimbas pada hak-hak anak yang harus dipenuhi oleh orang tua khususnya ayah akan terwujud dan mendapatkan perlindungan dari hukum Negara. Anak dapat memiliki Akta Kelahiran, karena orang tua memiliki Akta Nikah, anak mendapatkan hak warisan jika ayahnya meninggal dunia, anak berhak mendapatkan kehidupan yang sejahtera lahir dan bathin, layak mendapatkan pendidikan.

\section{KESIMPULAN}

Berdasarkan hasil penelitian tentang perkawinan poligami yang tidak tercatat, maka dapat disimpulkan bahwa pencatatan perkawinan yang tidak dilakukan oleh beberapa masyarakat Kota Panton Labu.

Faktor yang menyebabkan terjadinya perkawinan poligami yang tidak tercatat dilakukan tanpa ada izin dari isteri pertama. Dan kurangnya pemahaman terhadap syarat-syarat dan alasan yang membolehkan melakukan perkawinan poligami yang telah diatur dalam Undang-Undang Perkawinan dan Kompilasi Hukum Islam dengan secara ketat.

Akibat hukum dari perkawinan poligami yang tidak dicatat terhadap anak dan juga isteri sangatlah merugikan baik secara hukum atau sosial terutama isteri dianggap tidak sah, tidak berhak mendapatkan warisan bila suaminya meninggal dunia, dan tidak berhak atas harta gono-gini jika terjadi perpisahan dan kurangnya kasih sayang. Dan juga dampak dari anak yang dilahirkan dari perkawinan poligami yang tidak tercatat yaitu , anak tidak dapat mengurus akta kelahiran karena orang tua nya tidak memiliki akta nikah.

Penyelesaian hukum terhadap perkawinan poligami yang tidak tercatat, dengan melakukan permohonan suami isteri dengan cara perihal permohonan pengesahan nikah sirri poligami dengan cara Itsbah Nikah apabila putusan hakim mengabulkan gugatan pengesahan nikah sirri poligami yang diajukan tersebut, maka dapat dijadikan dasar pencatatan pernikahan sirri, selanjutnya pemohon dapat mengurus pencatatannya di Kantor Urusan Agama setempat dan untuk administrasi kependudukan lainnya dapat dilakukan di Kantor Administrasi kependudukan dan Catatan Sipil setempat termasuk untuk pengurusan Akta Kelahiran anak. 


\section{DAFTAR PUSTAKA}

Abdul Rahman G., Fiqih Munakahat, Kencana Prenada Media Group, Jakarta, 2003.

Asrorum Ni'am S., Fatwa-Fatwa Masalah Pernikahan dan Keluarga, Jakarta, 2008.

Bambang Sunggono., Metode Penelitian Hukum, Cetakan Ketiga, UI Press, Jakarta, 1986.

Hasan Edy, Poligami Syariah dan Perjuangan Kaum Perempuan, Alfabeta, Bandung, 2007

Labib MZ., Pembelaan Ummat Manusia, Bintang Pelajar, Surabaya, 2006.

Muhammad Shahrur., Metodologi Fiqh Islam Kontemporer, Elsas Press, Yogyakarta, 2006.

Mukti Jafar ND, Yulianto A., Dualisme Penelitian Hukum, Normatif dan Empiris, Yogyakarta, 2010.

Murtadha M., Citra Wanita Terhormat, Pustaka Zahra, Jakarta, 2003.

Subekti R, Tjitrosudibio R., Kitab Undang-Undang Hukum Perdata, Jakarta, 2002

Zainuddin Ali., Metode Penelitian Hukum, Sinar Grafika, cetakan kelima, Jakarta, 2014.

Masykurotus Syarifah, 2018, Implikasi Yuridis Poligami Bawah Tangan Persepktif UU No 1 Tahun 1974 Tentang Perkawinan, Jurnal skripsi, Sekolah Tinggi Agama Islam (STAI), Vol. 19 No. 1. 